\title{
REINFORCING WOODEN COMPOSITE WITH GLASS FIBER FABRIC - MANUFACTURING TECHNOLOGY AS A FACTOR LIMITING MECHANICAL PROPERTIES AND RELIABILITY
}

\author{
ZBROJENIE KOMPOZYTU DREWNIANEGO \\ WLÓKNEM SZKLANYM - WPLYW TECHNOLOGII \\ WYKONANIA NA WŁASNOŚCI MECHANICZNE \\ I NIEZAWODNOŚĆ
}

\author{
Adam Deskiewicz ${ }^{1}$, Michał Kowalik' ${ }^{2}$, Michał Milewicz ${ }^{3}$, \\ Marek Matyjewski ${ }^{4}$, Rafal Perz ${ }^{5}$ \\ 1,2,4,5 Warsaw University of Technology, Politechnika Warszawska, \\ ${ }^{3}$ Alternative Longboards \\ adeskiewicz@meil.pw.edu.pl; mkowalik@meil.pw.edu.pl; \\ michal@alternativelongboards.pl; mmatyjew@meil.pw.edu.pl; \\ rperz@meil.pw.edu.pl (corresponding author)
}

\begin{abstract}
This paper investigates the strength and reliability of the wooden composites reinforced with glass fiber for the skateboard application. Three different methods of glass-fiber reinforcement have been used to prepare totally 94 samples, including control trial. Two lamination methods have been utilized: vacuum and HPL (High Pressure Lamination). Conducted analysis allowed to determine preferred production technique.
\end{abstract}

Keywords: wood, composites, glass-fiber, reliability

Streszczenie: Tematem tej pracy jest badnie wytrzymałości $i$ niezawodności kompozytu drewnianego wzmocnionego włóknem szkalnym na potrzeby produkcji deskorolek. Zastosowano 3 różne metody zbrojenia włóknem szklanym oraz przygotowano próbę kontrolna, bez zbrojenia. Wykorzystano dwie metody przygotowania kompozytu: próżniowa oraz prawsowania pod wysokim ciśnieniem -HPL (High Pressure Lamination). Lacznie przebadano 94 próbki na trzy punktowe zginanie. Przeprowadzone badania pozwolity wytypować preferowana metode produkcji.

Stowa kluczowe: drewno, kompozyty, wtókno szklane, niezawodność 
Reinforcing wooden composite with glass fiber fabric - manufacturing technology.. Zbrojenie kompozytu drewnianego włóknem szklanym - wpływ technologii...

REINFORCING WOODEN COMPOSITE WITH GLASS FIBER FABRIC - MANUFACTURING TECHNOLOGY AS A FACTOR LIMITING MECHANICAL PROPERTIES AND RELIABILITY

\section{Introduction}

Composite structures these days tend to replace materials that have been used in wide range of industries. It is the transport industry where composites find particularly numerous applications such as cars (motorsports), yachts (where glass fiber laminates have been used as the primary structural material for many years; Figure 1.), aircraft (one of the most representative and recent examples is Boeing 787 "Dreamliner", structure of which consists of composite materials in c.a. 50\% including the most critical part - the wing).
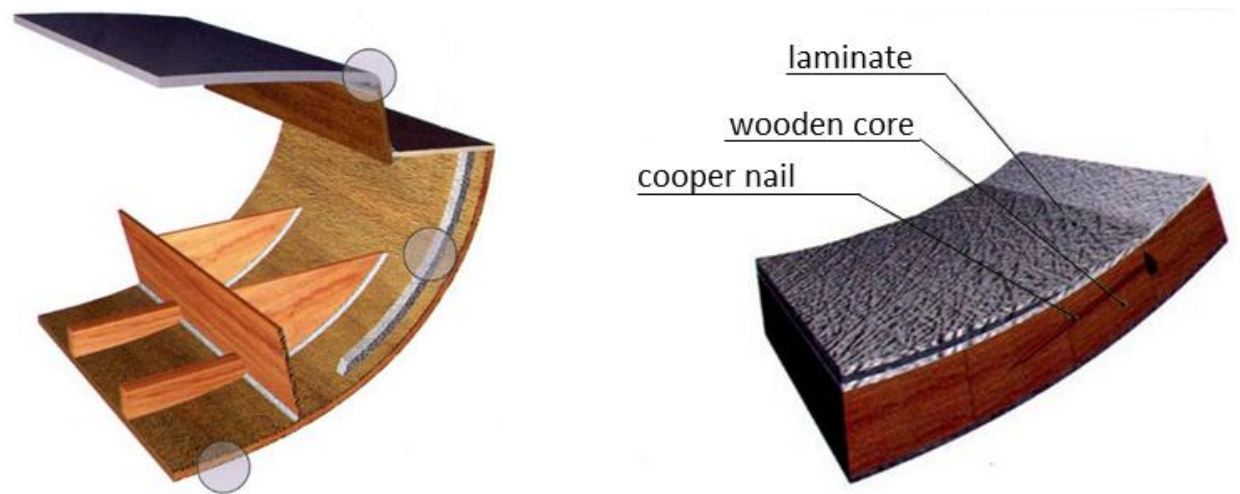

Fig. 1. Sailboat structure based on woden-core composite (source: Maciej Roszkowski, Mam jacht: Zakupy, Naprawy, Przebudowa, 2013) [1]

Yet, composites do not appear only in advanced structures and machinery. It is also manufacturers of simpler structures, such as skateboards, who tend to apply composite materials in their products. So far, typical longboards and skateboards (precisely their decks) have been manufactured by the process of forming the plywood at elevated temperature. Currently some innovative constructors aiming at high quality of their products make use of the laminates with a wooden core (not a plywood any more) and carbon/glass/Kevlar fiber reinforced polymers arranged in various configurations. Due to the complex nature of composite materials they are rather difficult to analyze numerically, therefore, while seeking lighter and at the same time durable and reliable solutions experimental testing is employed to find an optimal configuration. The quality of a composite component is also strongly influenced by its manufacturing technology. Thus, besides the right material choice, developing an appropriate manufacturing process is the crucial part of each reliable product. 

Michat Milewicz, Marek Matyjewski, Rafat Perz

This study describes the research on wood-glass-epoxy composites used in manufacturing of high performance longboards. The aim of the study was to find the optimal fabric to reinforce the wood laminate and assess the laminates manufacturing process in terms of reliability, strength and other mechanical properties of the material. Specific objectives of the research were:

- examination of the influence of fibers direction on the behavior of the composite;

- analysis of the repeatability of manufacturing by used methods;

- determination of the optimal wood-glass-epoxy composite configuration allowing it to be as light as possible;

- comparison of the properties of laminates manufactured by two different methods (vacuum forming and pressing at high temperature).

Before the research was carried out the following properties of analysed structures had been anticipated:

- increase of flexural strength with increasing number of fiber directions

- higher strength and the same or smaller mass of samples manufactured by the HPL (High Pressure Lamination) method since it is more expensive and advanced than vacuum forming

\section{Methods}

Composite plates roughly of the size of a typical longboard (c.a. $100 \times 25 \mathrm{~cm}$ ) and layout shown in Figure 2 were prepared for the purpose of the research. Subsequently, they were cut into samples of dimensions $300 \times 47 \mathrm{~mm}$. Thickness and mass of samples depended on the production series and reinforcement fabric applied.

\section{Fiberglass}

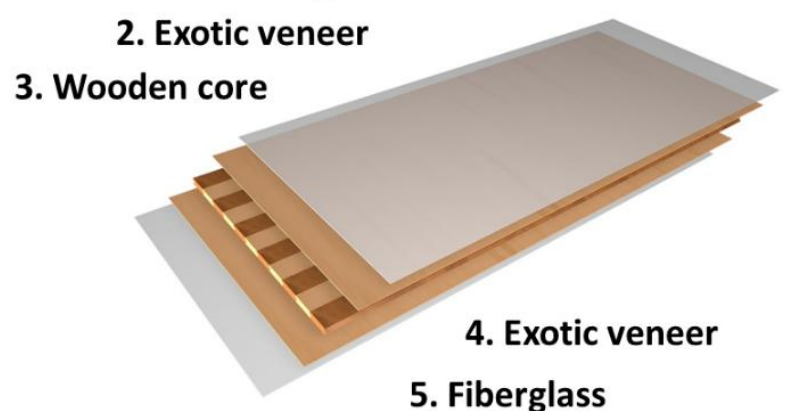

Fig. 2. Sample schematics

The base of the composite was a wooden core of $6 \mathrm{~mm}$ thickness consisting of ash and linden wooden splines adhered alternately $\left(\mathrm{V}\right.$-tech ${ }^{\circledR}$ technology [2]) covered on both sides by the veneer of 1-1.5 mm thickness. 
Reinforcing wooden composite with glass fiber fabric - manufacturing technology.. Zbrojenie kompozytu drewnianego włóknem szklanym - wpływ technologii...

The composite (with the exception of the control sample) was covered on both sides by the glass fabric. All samples have been manufactured with the use of Epidian 5 epoxy resin and IDA hardener. Detailed description of the samples and applied fabrics is presented in Table 1 .

\begin{tabular}{|c|c|c|}
\multicolumn{1}{c|}{} & Table 1. Samples description \\
\cline { 2 - 3 } \multicolumn{1}{c|}{} & Layers scheme & $\begin{array}{c}\text { Fiberglass fabric } \\
\text { weight }\left(\mathrm{g} / \mathrm{m}^{2}\right)\end{array}$ \\
\hline $\begin{array}{c}\text { Control trial } \\
\text { Fiberglass laminate } \\
\text { 2-ply }\end{array}$ & $\begin{array}{c}\text { Veneer + Core + Veneer } \\
\text { Vener + Core + Veneer }\end{array}$ & N/A \\
\hline $\begin{array}{c}\text { Fiberglass laminate }\left[+45^{\circ} ;-45^{\circ}\right] \\
\text { 3-ply }\end{array}$ & $\begin{array}{c}\text { Veneer + Core }+ \text { Veneer } \\
2 x \text { fabric }\left[+45^{\circ} ;-45^{\circ} ; 0^{\circ}\right]\end{array}$ & 600 \\
\hline $\begin{array}{c}\text { Fiberglass laminate } \\
\text { 4-ply }\end{array}$ & $\begin{array}{c}\text { Veneer + Core }+ \text { Veneer } \\
2 \mathrm{x} \text { fabric } \\
{\left[+45^{\circ} ;-45^{\circ} ; 0^{\circ} ; 90^{\circ}\right]}\end{array}$ & 810 \\
\hline
\end{tabular}

The analysis governed also the process of manufacturing above samples. In total, 94 samples were prepared, 59 of which were manufactured with the HPL method and 35 remaining with the vacuum forming (Table 2.) [3, 4]. High Pressure Lamination incorporates forming samples with the use of hydraulic press under the pressure of 6.5 bar with concurrent heat treatment at 75 degrees for 120 minutes. While applying this method attention was paid to the rate at which a component was heated and cooled (c.a. $10^{\circ} \mathrm{C} / \mathrm{min}$ ), since it has a significant impact on the product quality. The HPL manufacturing of composites primarily allows achieving higher fiber to resin ratios. Vacuum forming method consists of inserting the saturated laminate covered by the layer of air-bubbles distributing material and separator into the sealed bag from which air is sucked by the vacuum pump $[3,4]$. The advantages of vacuum forming are its simplicity and relatively low cost. However, it is worth noting that the pressure acting on the laminate has the maximum value of 1 bar and the laminate hardens in room temperature.

Table 2. Sample types quantity

\begin{tabular}{|l|l|c|}
\hline \multicolumn{3}{|c|}{ Vacuum Method } \\
\hline & \multicolumn{1}{|c|}{ Configuration } & $\begin{array}{l}\text { Samples } \\
\text { quantity }\end{array}$ \\
\hline 1. & Control trial & 9 \\
\hline 2. & 2-ply fiberglass & 9 \\
\hline 3. & 3-ply fiberglass & 7 \\
\hline 4. & 4-ply fiberglass & 10 \\
\hline
\end{tabular}

\begin{tabular}{|l|l|c|}
\hline \multicolumn{3}{|c|}{ HPL Method } \\
\hline & \multicolumn{1}{|c|}{ Configuration } & $\begin{array}{l}\text { Samples } \\
\text { quantity }\end{array}$ \\
\hline 5. & Control trial & 14 \\
\hline 6. & 2-ply fiberglass & 15 \\
\hline 7. & 3-ply fiberglass & 15 \\
\hline 8. & 4-ply fiberglass & 15 \\
\hline
\end{tabular}

For the clarity, the samples were numbered. 
In the experiment specimens were subjected to three-point bending [5, 6]. All tests were performed with the use of Instron strength machine. The specimen was placed on two cylindrical supports of $10 \mathrm{~mm}$ diameter at $250 \mathrm{~mm}$ distance between their axes. The load was applied centrally through a cylinder of $40 \mathrm{~mm}$ diameter at the pace of $2 \mathrm{~mm} / \mathrm{s}$. It was the actuator position which was controlled numerically (Figure 3.). Recorded parameters were time, actuator position and force.
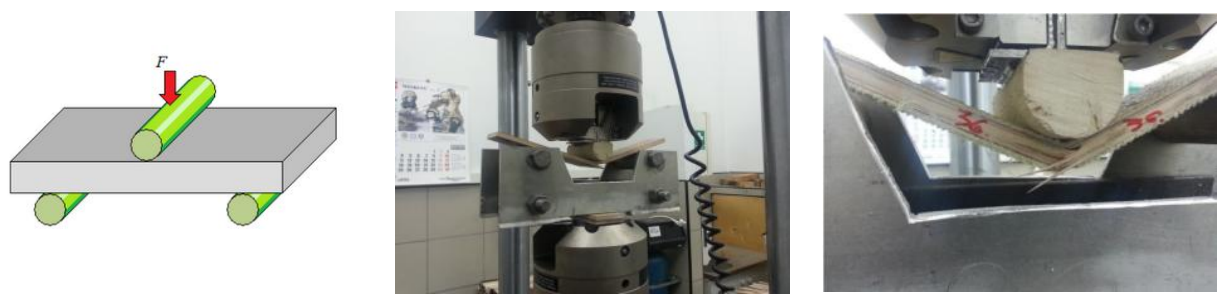

Fig. 3. Three-point bending schematics and experimental stand photos

Results obtained during the tests have been subsequently analyzed. The following parameters have been determined for each sample: stiffness, maximum load and maximum load to mass ratio.

\section{Results}

Mean values obtained with the results are shown in Figures 4 to 9. The charts illustrate the comparison between the values obtained for specimens manufactured by the vacuum forming and HPL methods. Each mean value is also accompanied by the standard deviation.

In Figure 4. average mass of the respective specimen groups is presented. It may be observed, that samples with the glass fiber layer produced by vacuum forming are characterized by $9-26 \%$ higher mass, which may be explained by the higher resin content. It is confirmed by Figure 5., where higher resin-to-fiber mass ratio is observed. It also indicates that higher pressure applied in the HPL method causes more resin to escape the laminate than in the case of vacuum forming technique.

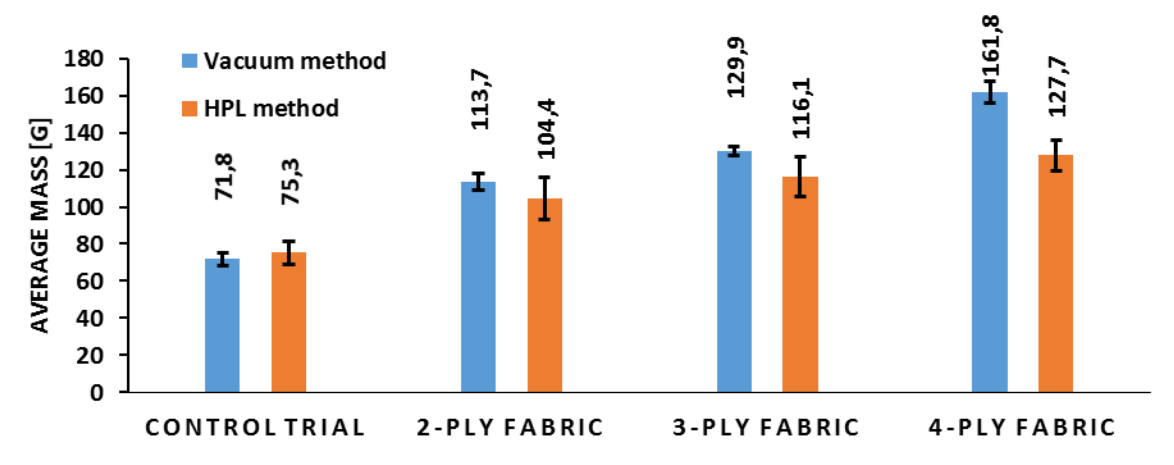

Fig. 4. Average mass of a sample 
Reinforcing wooden composite with glass fiber fabric - manufacturing technology.. Zbrojenie kompozytu drewnianego włóknem szklanym - wptyw technologii...

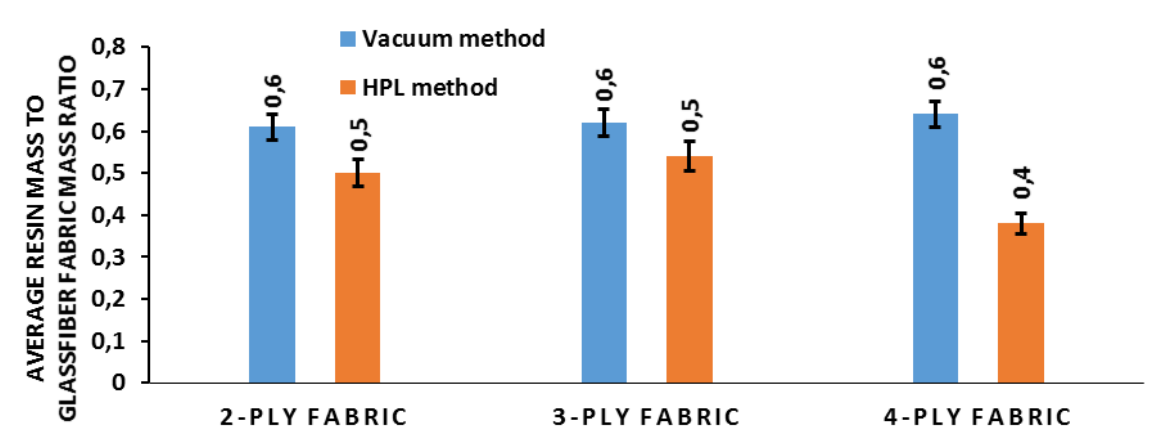

Fig. 5. Average resin mass to fiberglass fabric mass ratio

The maximum deflection observed for all specimens was similar. Fracture occurred at deflections of $12-14 \mathrm{~mm}$ (Figure 6.). However, the maximum load was higher for vacuum formed specimens. Test samples with 2- and 3-ply glass fabrics showed flexural strength higher by $25 \%$ and in case of 4-ply fabric the load carried by vacuum formed specimens was $65 \%$ higher than in case of specimens manufactured by the HPL method. (Figure 7.). The maximum load endured by control samples was comparable, however the fracture occurred at significantly smaller deflections.

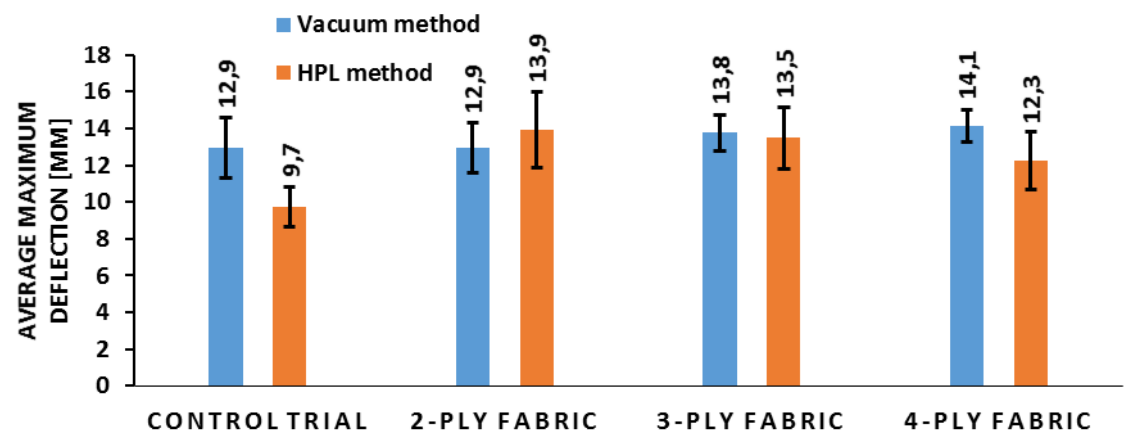

Fig. 6. Average maximum deflection of a sample

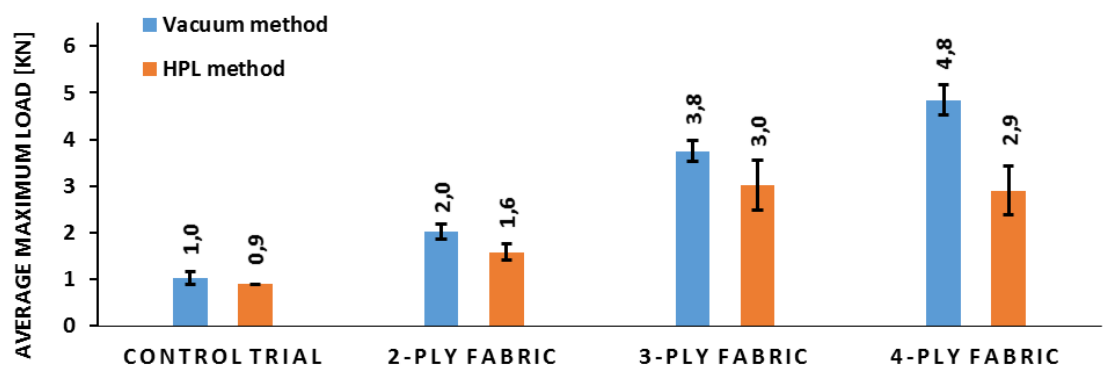

Fig. 7. Average maximum load of a sample 

Michat Milewicz, Marek Matyjewski, Rafat Perz

The force vs. displacement curves obtained during the bending tests were close to linear. Therefore, a linear approximation of each test has been performed in order to determine the average stiffness of examined specimens. The outcomes show that glass fiber reinforced specimens produced by vacuum forming are stiffer by 20 45\% than the respective specimens produced by High Pressure Lamination (Figure 8.), which in case of longboards is not a desired feature.

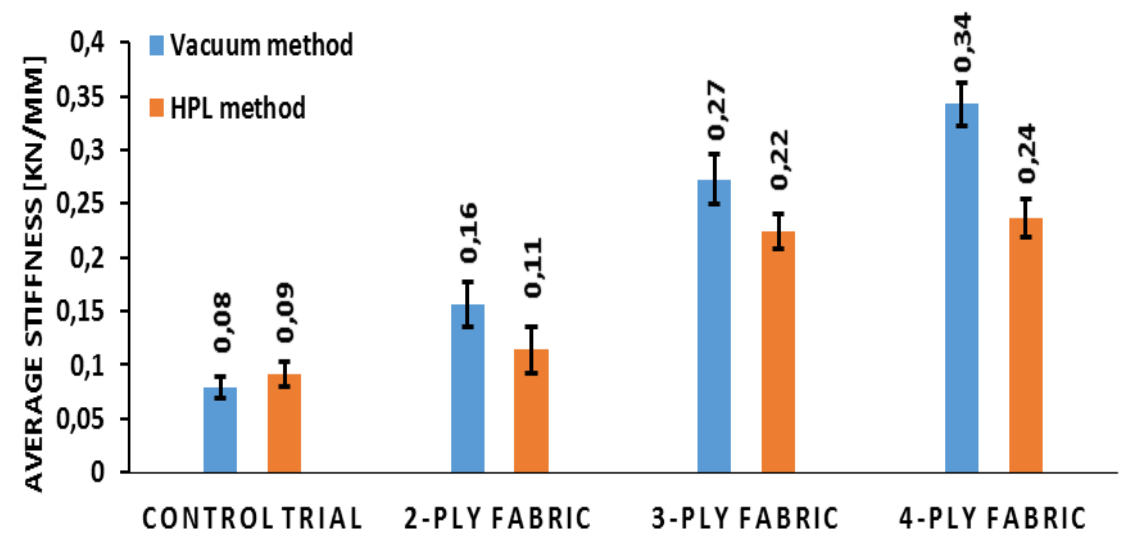

Fig. 8. Average stiffness of a sample

Finally, the maximum load to mass ratio has been analyzed (figure 9.). Here, vacuum formed composite specimens seem to have better characteristics by roughly $10-30 \%$. It indicates the possibility of too low resin content in HPL manufactured specimens.

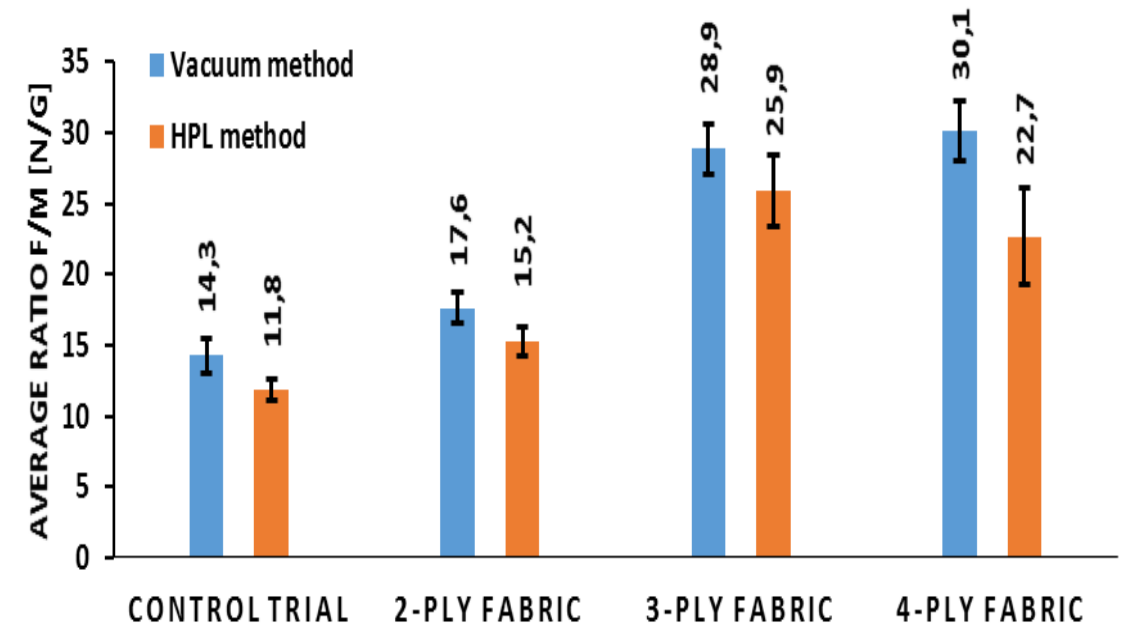

Figure 9. Average maximum load to mass of a sample ratio 
Reinforcing wooden composite with glass fiber fabric - manufacturing technology.. Zbrojenie kompozytu drewnianego włóknem szklanym - wpływ technologii...

Detailed mean data obtained in the experiments are presented in Table 3.

Table 3. Detailed experimental results

\begin{tabular}{|c|c|c|c|c|c|c|}
\hline \multicolumn{7}{|c|}{ Vacuum Method Samples } \\
\hline & $\begin{array}{c}\text { Average } \\
\text { mass } \\
{[\mathrm{g}]}\end{array}$ & $\begin{array}{c}\text { Average } \\
\text { resin mass } \\
\text { to } \\
\text { fiberglass } \\
\text { fabric mass } \\
\text { ratio [-] }\end{array}$ & $\begin{array}{c}\text { Average } \\
\text { maximum } \\
\text { deflection } \\
{[\mathrm{mm}]}\end{array}$ & $\begin{array}{c}\text { Average } \\
\text { maximum } \\
\text { load } \\
{[\mathrm{N}]}\end{array}$ & $\begin{array}{c}\text { Average } \\
\text { stiffness } \\
{[\mathrm{kN} / \mathrm{mm}]}\end{array}$ & $\begin{array}{c}\text { Average } \\
\text { max. load } \\
\text { to mass of } \\
\text { a sample } \\
\text { ratio } \\
{[\mathrm{N} / \mathrm{g}]}\end{array}$ \\
\hline 1. & 71,78 & - & 12,9 & 1024,90 & 0,079 & 14,25 \\
\hline 2. & 113,67 & 0,61 & 12,9 & 2023,15 & 0,156 & 17,63 \\
\hline 3. & 129,86 & 0,62 & 13,8 & 3750,31 & 0,273 & 28,88 \\
\hline 4. & 161,80 & 0,64 & 14,1 & 4846,24 & 0,345 & 30,10 \\
\hline
\end{tabular}

\begin{tabular}{|c|c|c|c|c|c|c|}
\hline \multicolumn{7}{|c|}{ HPL Method Samples } \\
\hline & $\begin{array}{c}\text { Average } \\
\text { mass } \\
{[\mathrm{g}]}\end{array}$ & $\begin{array}{c}\text { Average } \\
\text { resin mass } \\
\text { to } \\
\text { fiberglass } \\
\text { fabric mass } \\
\text { ratio [-] }\end{array}$ & $\begin{array}{c}\text { Average } \\
\text { maximum } \\
\text { deflection } \\
{[\mathrm{mm}]}\end{array}$ & $\begin{array}{c}\text { Average } \\
\text { maximum } \\
\text { load } \\
{[\mathrm{N}]}\end{array}$ & $\begin{array}{c}\text { Average } \\
\text { stiffness } \\
{[\mathrm{kN} / \mathrm{mm}]}\end{array}$ & $\begin{array}{c}\text { max. load } \\
\text { to mass of } \\
\text { a sample } \\
\text { ratio } \\
{[\mathrm{N} / \mathrm{g}]}\end{array}$ \\
\hline 5. & 75,29 & - & 9,7 & 890,96 & 0,092 & 11,84 \\
\hline 6. & 104,40 & 0,50 & 13,9 & 1584,77 & 0,114 & 15,22 \\
\hline 7. & 116,07 & 0,54 & 13,5 & 3023,28 & 0,224 & 25,89 \\
\hline 8. & 127,73 & 0,38 & 12,3 & 2901,46 & 0,237 & 22,67 \\
\hline
\end{tabular}

\section{Discussion}

It is important to mention that this research is intended to act as a comparative analysis, done for production purposes and it does not relate to other commercially available composites. The research based on the method described earlier is still in progress and it is aimed at thorough analysis of material parameters and adjustment of manufacturing process parameters. The analysis presented in this article acts as an introduction to the research activities which are now at high stage of advancement.

Presented results comparing characteristics of specimens manufactured by HPL and vacuum forming methods may seem unexpected. More technologically advanced HPL method appeared to result in worse products in nearly all aspects of interest. It turned out that specimens produced by vacuum forming, despite being heavier, show higher absolute flexural strength as well as higher maximum load to mass ratio.

Moreover, they failed at larger deflections. It is only the stiffness which seem to be more advantageous in case of HPL manufactured specimens, as longboard's good handling properties require the material to be sufficiently flexible. There may be a few reasons of such observations and most probably these are errors by the manufacturing and usage of an improper resin for the applied methods. It might be presumed that the process parameters such as temperature and pressure were 
insufficiently adjusted resulting in lighter, but at the same time weaker specimens (thanks to the lower resin content).

The initial assumption of increasing composite flexural strength with increasing number of layers and fiber directions has been confirmed by the experiment results, as shown in Table 3. However, adding 4th (transverse) direction is an exception to this rule, giving varying results depending on the method of manufacturing of the test specimen. Nevertheless, a small improvement (vacuum method) or even the deterioration (HPL method) of composite performance after adding the 4th direction of fibers suggests, that such fabric is not the right choice for the reinforcement of longboard laminates. It is, yet, difficult to indicate a single configuration which will be the optimal solution. On the one hand, 2-ply fabric is characterized by a lower stiffness resulting in more flexible product that fails at similar deflection to the one of the 3-ply fabric reinforced specimens. On the other hand, the failure occurs under a significantly lower load. The final choice of the best configuration needs further study to be carried out, both in the laboratory and in the field (of the ready product).

As far as the manufacturing technology of composites is concerned, despite obtaining worse results than expected the High Pressure Lamination is still the preferred method in case of longboard production. It is so due to the fact that HPL enables the regulation of the production parameters which results in higher ability to adjust the material properties. Additionally, the vacuum forming appears to involve insufficient pressure to generate a desired surface profile. The application of autoclave could resolve this issue. Another reason why HPL is the preferred method is its shorter duration by up to a few times. Finally, the aesthetical aspect is taken into consideration. It is easier to produce a final product with fine surface finish by the HPL method.

\section{Summary and conclusions}

Summing up the activities performed a few conclusions may be drawn with significant implications in future production process. Firstly, the HPL method unexpectedly appeared to be less effective in comparison to the vacuum forming in the tests performed. This result is probably caused by insufficient manufacturing process parameters adjustment. As it had been anticipated, an increase of flexural strength of the composite was observed after adding consecutive layers and fiber directions to the reinforcement. Moreover, the preferred reinforcement configurations have been indicated to meet the mechanical properties requirements - stiffness and flexural strength. It is, however, necessary to carry out further studies aimed at optimizing the HPL manufacturing process parameters. Attempts of performing the experiment with the use of different resins should be also made. This research is still ongoing.

\section{References}

[1] Maciej Roszkowski, Mam jacht: Zakupy, Naprawy, Przebudowy, Alma-Press Sp. Z o.o., 2013.

[2] Strona internetowa: http://alternativelongboards.pl/.

[3] Gibson Roland F., Principles of composite material mechanics, Third edition. CRC Press, 2012.

[4] Mallick P. K., Fiber-Reinforced Composites: Materials, Manufacturing, and Design, Third Edition. CRC Press, 2007. 
Reinforcing wooden composite with glass fiber fabric - manufacturing technology.. Zbrojenie kompozytu drewnianego włóknem szklanym - wpływ technologii...

[5]Polski Komitet Normalizacyjny: PN-EN ISO 178:2011/A1:2013-06 - wersja angielska.

[6]Polski Komitet Normalizacyjny: PN-EN 12135:2001 - wersja polska.

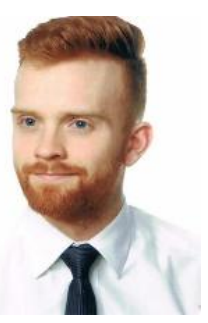

Adam Deskiewicz Eng. in 2016 graduated in Aerospace Engineering with B.Sc. (engineer) degree from the Faculty of Power, Mechanical and Aeronautical Engineering at the Warsaw University of Technology. Currently he is a M.Sc. student at the same faculty. Scientific interests are aircraft (manned and UAV) design and aircraft structures analysis. (Share: 40\%).

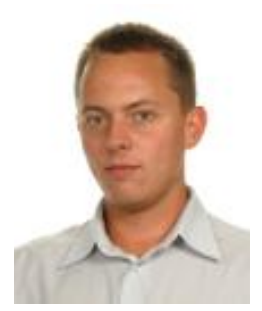

Michat Kowalik M.Sc. Eng. in 2009 graduated with M.Sc. (engineer) degree from the Faculty of Power, Mechanical and Aeronautical Engineering at the Warsaw University of Technology. Currently works as a Graduate Research Assistant at the Institute of Aeronautics and Applied Mechanics. Scientific interests are biomechanics, experimental methods in mechanics, natural and sythetic composite materials. (Share: 15\%).

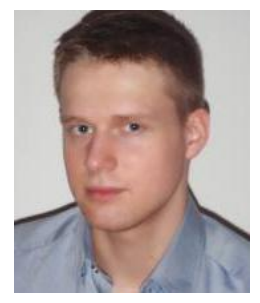

Michat Milewicz co-founder and owner of the Alternative Longboards company. Since 2010 he works on board-sports technologies. Enthusiast of the open source projects. Currently focused on the company development and innovations in longboards production. Scientific interests are manufacturing technologies, resin based composite materials, machine design, automatics, electronics and open source community. (Share: 15\%).

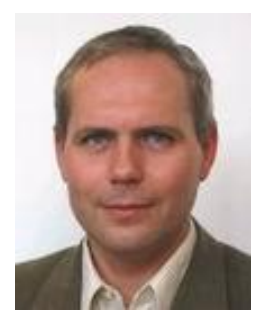

Marek Matyjewski, Assoc. Prof. PhD. Eng. in 1988 graduated with M.Sc. (engineer) degree from the Faculty of Power, Mechanical and Aeronautical Engineering at the Warsaw University of Technology. In 1996 obtained Ph.D. degree. Currently works as a professor at the Institute of Aeronautics and Applied Mechanics. Scientific interests are biomechanics, vehicle passive safety and human reliability. (Share: 10\%).

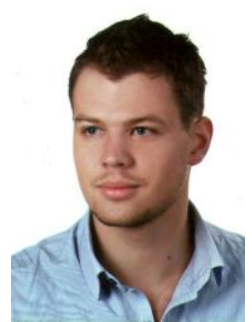

Rafat Andrzej Perz M.Sc. Eng. in 2010 graduated with M.Sc. (engineer) degree from the Faculty of Power, Mechanical and Aeronautical Engineering at the Warsaw University of Technology. Currently works as a Graduate Research Assistant at the Institute of Aeronautics and Applied Mechanics. Scientific interests are injury biomechanics, vehicle passive safety and crash investigation, reliability and composite materials. (Share: 20\%). 


\section{ZBROJENIE KOMPOZYTU DREWNIANEGO WLÓKNEM SZKLANYM - WPLYW TECHNOLOGII WYKONANIA NA WLASNOŚCI MECHANICZNE I NIEZAWODNOŚĆ}

\section{Wstęp}

W dzisiejszych czasach konstrukcje kompozytowe stale zastępują tradycyjne materiały. Dotyczy to znacznej większości dziedzin przemysłu. Szczególnie szerokie zastosowania kompozyty znajdują $\mathrm{w}$ środkach transportu takich jak samochody (zwłaszcza pojazdy sportowe, wyczynowe), jachty (laminaty szklane używane są jako podstawowy materiał konstrukcyjny już od wielu lat; Rysunek 1.), samoloty (jako najbardziej reprezentatywny i jeden z najnowszych przykładów można tu podać szerokokadłubowy samolot pasażerski Boeing 787 "Dreamliner", w którym około 50 procent całej konstrukcji, a w tym elementy kluczowe skrzydła, wyprodukowano z różnego rodzaju kompozytów).
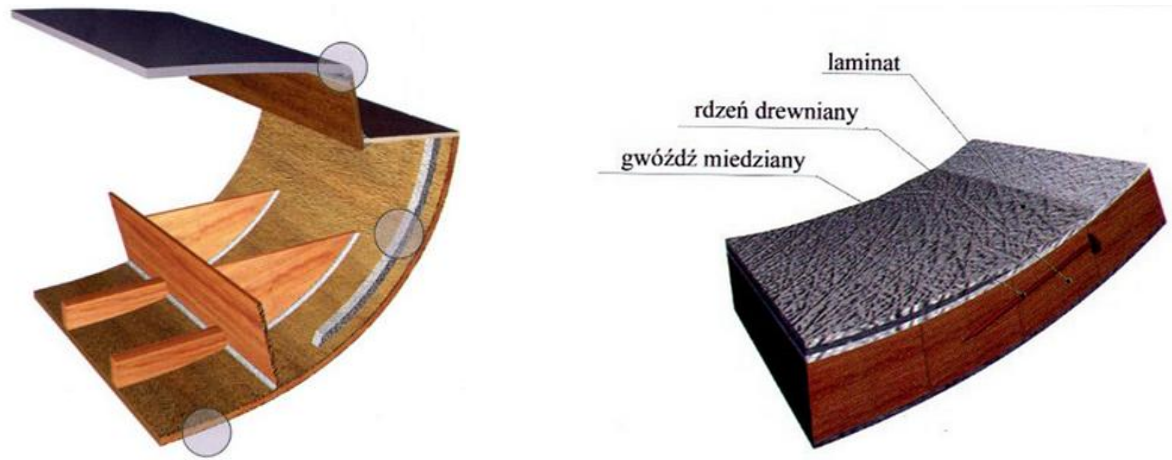

Rys. 1. Struktura jachtu bazujaca na kompozycie z drewnianym rdzeniem (źródto: Maciej Roszkowski, Mam jacht: Zakupy, Naprawy, Przebudowa, 2013) [1]

Jednak kompozyty to nie tylko zaawansowane budowle i maszyny. Również producenci prostszych konstrukcji, na przykład deskorolek, coraz chętniej sięgają po kompozyty. Do tej pory typowe deskorolki, a dokładniej blaty deskorolek, wytwarzane były z profilowanej na gorąco sklejki drewnianej. Obecnie niektóre innowacyjne przedsiębiorstwa stawiające na wysoką jakość swoich produktów, wykorzystują laminaty składające się z drewnianego rdzenia (już nie sklejki), przekładek $\mathrm{z}$ włókna węglowego oraz pokrywających go warstw zbrojenia na przykład włóknem szklanym lub aramidowym. Ze względu na złożoną strukturę wewnętrzną, kompozyty są materiałami trudnymi w analizie numerycznej, stąd szukając rozwiązań lżejszych, a przy tym nadal wytrzymałych i niezawodnych, producenci stawiają na badania eksperymentalne, szukając optymalnego doboru komponentów. Na jakość kompozytowego elementu ogromny wpływ ma także technologia jego wykonania. 
Reinforcing wooden composite with glass fiber fabric - manufacturing technology.. Zbrojenie kompozytu drewnianego włóknem szklanym - wpływ technologii...

Dlatego poza doborem właściwych materiałów, opracowanie odpowiedniego procesu technologicznego jest niezbędnym składnikiem niezawodnego produktu.

Niniejsza praca opisuje proces badań kompozytów drewniano - szklanych wykorzystywanych do produkcji deskorolek typu „longboard”. Celem badań był dobór odpowiedniej tkaniny na zbrojenie laminatu drewnianego oraz ocena procesu technologicznego produkcji tych laminatów, tak aby materiał produkcyjny był wytrzymały, niezawodny i zarazem zachował pożądane właściwości mechaniczne. Szczegółowe cele badań zakładały:

- zbadanie wpływu kierunku włókien na zachowanie laminatu;

- analiza powtarzalności wykonania części użytymi metodami;

- znalezienie optymalnej konfiguracji kompozytu drewnianego przy zachowaniu jak najmniejszej masy;

- porównanie parametrów laminatu wykonanego dwoma różnymi metodami (próżniowo i w prasie z wygrzewaniem).

Przed wykonaniem opisanych badań spodziewane były następujące właściwości analizowanych struktur:

- podniesienie wytrzymałości na zginanie wraz z rosnącą liczbą kierunków tkaniny szklanej;

- metoda HPL (High Pressure Lamination), jako droższa i bardziej zaawansowana od metody próżniowej, powinna pozwolić na osiągnięcie wyższej wytrzymałości przy tej samej lub mniejszej masie próbek.

\section{Metody}

Na cele badań przygotowano płyty kompozytowe o gabarytach deskorolki typu „longboard” (ok. 100 x $25 \mathrm{~cm}$ ), wg schematu przedstawionego na rysunku 2. Następnie płyty zostały pocięte na próbki o wymiarach 300 x $47 \mathrm{~mm}$. Grubość i masa próbek zależała od serii i użytych tkanin zbrojących.

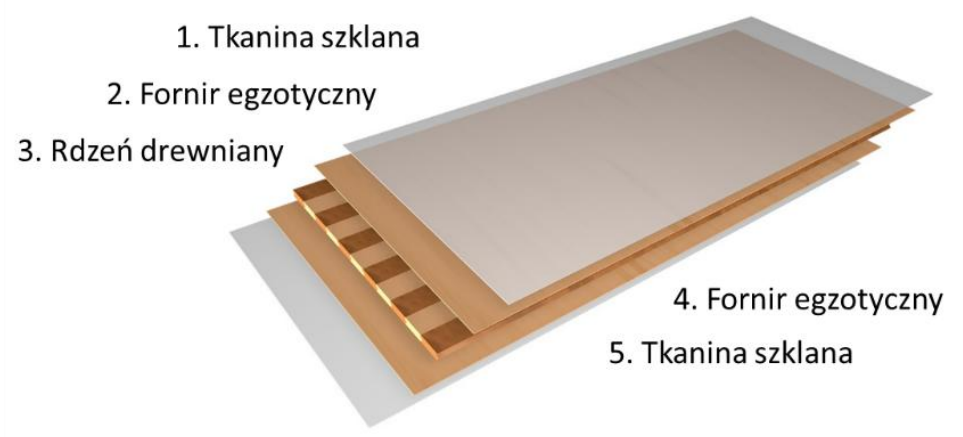

Rys. 1. Schemat budowy badanej próbki

Podstawą kompozytu był drewniany rdzeń, grubości $6 \mathrm{~mm}$, wykonany ze sklejonych naprzemiennie ( $w$ technologii $V$-tech ${ }^{\circledR}[2]$ ) listew jesionowych $\mathrm{i}$ lipowych pokryty z dwóch stron fornirem egzotycznym grubości ok. $1-1,5 \mathrm{~mm}$. 
Wierzch kompozytu (z wyjątkiem próby kontrolnej) z obydwu stron pokryty był tkaniną szklaną. Wszystkie próbki wykonane były przy użyciu żywicy epoksydowej Epidian 5 oraz utwardzacza IDA. Szczegółowy opis próbek oraz użytych tkanin znajduje się w tabeli 1.

Tabela1. Opis użytych próbek

\begin{tabular}{|c|c|c|}
\cline { 2 - 3 } \multicolumn{1}{c|}{} & \multicolumn{2}{c|}{ Tabelal. Opis użytych próbek } \\
\cline { 2 - 3 } \multicolumn{1}{c|}{} & Układ warstw & $\begin{array}{c}\text { Gramatura tkaniny } \\
\text { szklanej }\left(\mathrm{g} / \mathrm{m}^{2}\right)\end{array}$ \\
\hline Próbka kontrolna & Fornir + Rdzeń + Fornir & nie dotyczy \\
\hline $\begin{array}{c}\text { Laminat szklany } \\
\text { 2-kierunkowy }\end{array}$ & $\begin{array}{c}\text { Fornir + Rdzeń + fornir } \\
\text { 2x tkanina }\left[+45^{\circ} ;-45^{\circ}\right]\end{array}$ & 600 \\
\hline $\begin{array}{c}\text { Laminat szklany } \\
\text { 3-kierunkowy }\end{array}$ & $\begin{array}{c}\text { Fornir + Rdzeń }+ \text { Fornir } \\
\text { 2x tkanina }\left[+45^{\circ} ;-45^{\circ} ; 0^{\circ}\right]\end{array}$ & 810 \\
\hline $\begin{array}{c}\text { Laminat szklany } \\
\text { 4-kierunkowy }\end{array}$ & $\begin{array}{c}\text { Fornir }+ \text { Rdzeń }+ \text { Fornir } \\
2 \mathrm{x} \text { tkanina }\left[+45^{\circ} ;-\right. \\
\left.45^{\circ} ; 0^{\circ} ; 90^{\circ}\right]\end{array}$ & 1200 \\
\hline
\end{tabular}

Analiza objęła także wpływ metody wykonania powyższych próbek. W sumie przygotowano 94 próbek, z czego 59 wykonanych było metodą HPL, zaś 35 wykonano metodą próżniową (tabela 2.) $[3,4]$. Metoda HPL polega na wykonaniu próbek w prasie, pod naciskiem do 6.5 bar oraz jednoczesnym wygrzewaniu w temperaturze $75^{\circ} \mathrm{C}$, przez czas 120 minut. Stosując tę metodę, zwrócono szczególną uwagę na czas nagrzewania oraz schładzania elementu (około $10{ }^{\circ} \mathrm{C} / \mathrm{min}$ ), gdyż ma to duży wpływ na późniejszą jakość wyrobu. Wytwarzanie kompozytów metodą HPL pozwala przede wszystkim osiągnąć lepszy poziom przesączenia tkanin żywicą. Metoda próżniowa polega na umieszczeniu przesączonego laminatu pokrytego materiałem rozprowadzającym pęcherzyki powietrza i rozdzielaczem w worku, do którego podłączono pompę próżniową $[3,4]$. Zaletami próżniowego wytwarzania kompozytów jest jego prostota i niski koszt, należy jednak pamiętać, że ciśnienie, które działa na sprasowywany laminat ma wtedy wartość zaledwie 1 bar, a utwardzanie odbywa się w temperaturze otoczenia.

Tabela 2. Liczba próbek w poszczególnych konfiguracjach

\begin{tabular}{|l|l|c|}
\hline \multicolumn{3}{|c|}{ Metoda próżniowa } \\
\hline & \multicolumn{1}{|c|}{ Konfiguracja } & $\begin{array}{c}\text { Liczba } \\
\text { próbek }\end{array}$ \\
\hline 1. & Próba kontrolna & 9 \\
\hline 2. & Dwukierunkowa & 9 \\
\hline 3. & Trzykierunkowa & 7 \\
\hline 4. & Czterokierunkowa & 10 \\
\hline
\end{tabular}$\quad$\begin{tabular}{|l|l|c|}
\hline 5. & \multicolumn{3}{|c|}{ Konfiguracja } & $\begin{array}{c}\text { Liczba } \\
\text { próbek }\end{array}$ \\
\hline 6. & Dwóba kontrolna & 14 \\
\hline 7. & Trzykierunkowa & 15 \\
\hline 8. & Czterokierunkowa & 15 \\
\hline
\end{tabular}

W celu przejrzystości wyników poszczególne próby ponumerowano. 
Reinforcing wooden composite with glass fiber fabric - manufacturing technology.. Zbrojenie kompozytu drewnianego włóknem szklanym - wpływ technologii...

Eksperyment polegał na trzypunktowym zginaniu $[5,6]$. Testy przeprowadzono na maszynie wytrzymałościowej Instron. Próbka ułożona była na podporach walcowych o średnicy $10 \quad \mathrm{~mm}$ i rozstawie $250 \mathrm{~mm}$ oraz obciążana centralnie wałkiem o średnicy $40 \mathrm{~mm}$ z prędkością $2 \mathrm{~mm} / \mathrm{sek}$. Obciążanie sterowane było przesuwem dolnej głowicy (rysunek 3.). Podczas testu rejestrowane były czas, położenie głowicy oraz siła.
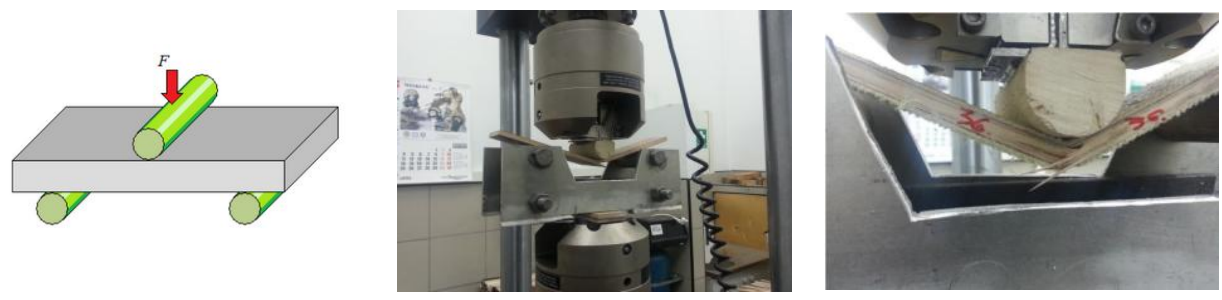

Rys. 3. Schemat obciążania próbek oraz zdjęcia stanowiska badawczego

Uzyskane podczas eksperymentu wyniki zostały poddane dalszej analizie. Dla każdej próbki wyznaczono następujące parametry: sztywność, obciążenie maksymalne oraz stosunek obciążenia maksymalnego do masy próbki.

\section{Wyniki}

Średnie wyniki poszczególnych rezultatów przedstawiono na rysunkach 4. do 9 . porównując jednocześnie wyniki metod próżniowej i HPL. Dla każdej wartości przedstawiono dodatkowo odchylenie standardowe.

Na rysunku 4. Przedstawiono średnie masy poszczególnych grup próbek. Widać wyraźnie, że laminaty wykonane metodą próżniową, zbrojone włóknem szklanym mają większą masę o ok. 9 - 26 \%, co świadczy o większej zawartości żywicy w kompozycie, co potwierdzone jest zresztą na rysunku 5., gdzie widać większy stosunek masy żywicy, do masy tkaniny szklanej. Jest to również informacja, że w wyniku wyższego ciśnienia podczas prasowania próbek metodą HPL, wyciskana jest większa ilość żywicy niż w przypadku metody próżniowej.

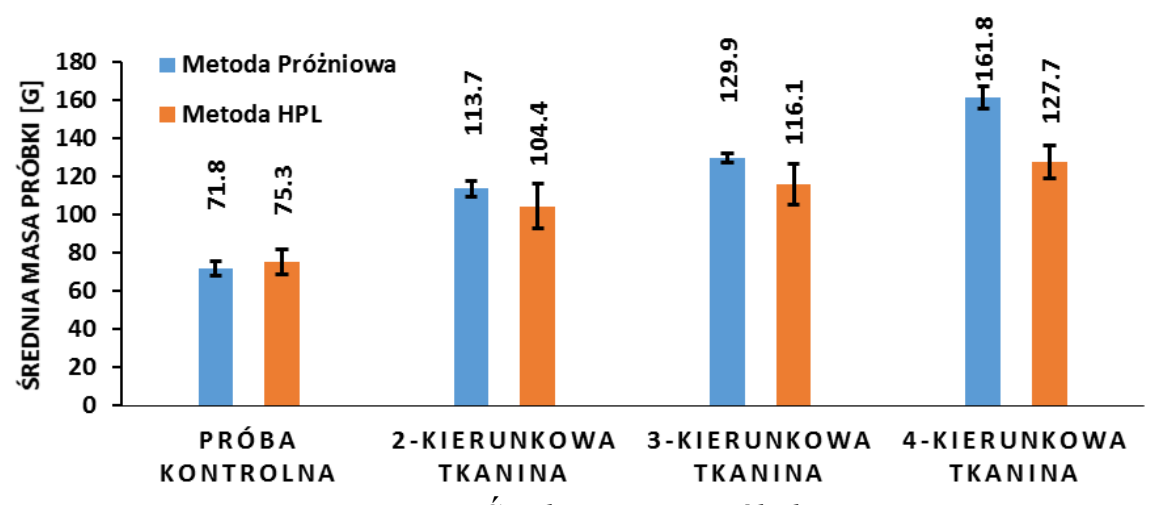

Rys. 4. Średnia masa próbek 


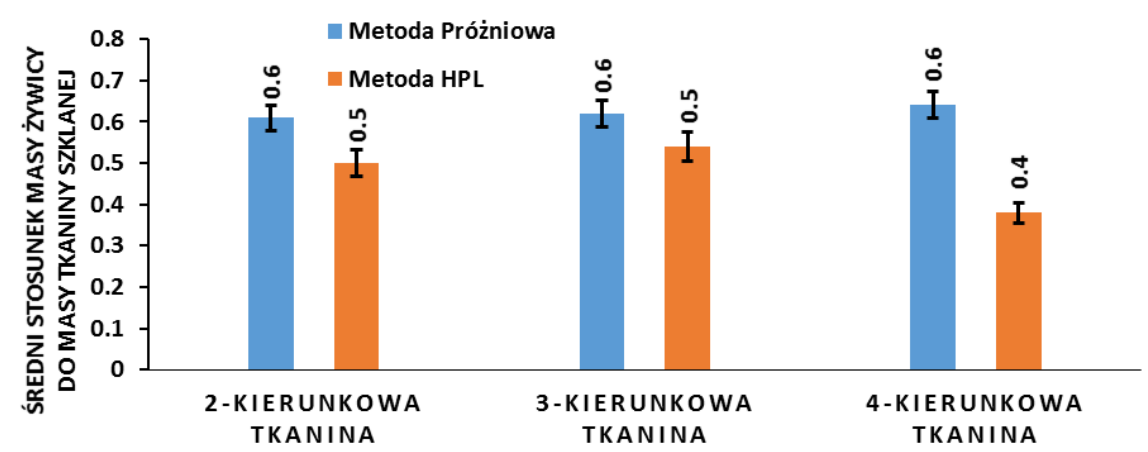

Rys. 5. Średni stosunek masy żywicy do masy tkaniny szklanej

Próbki wytrzymywały bardzo podobne maksymalne ugięcia i pękały przy wartościach ok. 12 - $14 \mathrm{~mm}$ (rysunek 6.). Jednak siły maksymalne różniły się na korzyść próbek wykonanych metodą próżniową. Próbki zbrojone tkaniną szklaną 2- i 3- kierunkową wytrzymywały obciążenie większe o ok. $25 \%$, zaś próbki zbrojone tkaniną szklaną 4- kierunkową aż o ok. 65\% (rysunek 7.). Próbki kontrolne wypadły podobnie w obciążeniu maksymalnym, jednak pękały przy znacznie mniejszym ugięciu.

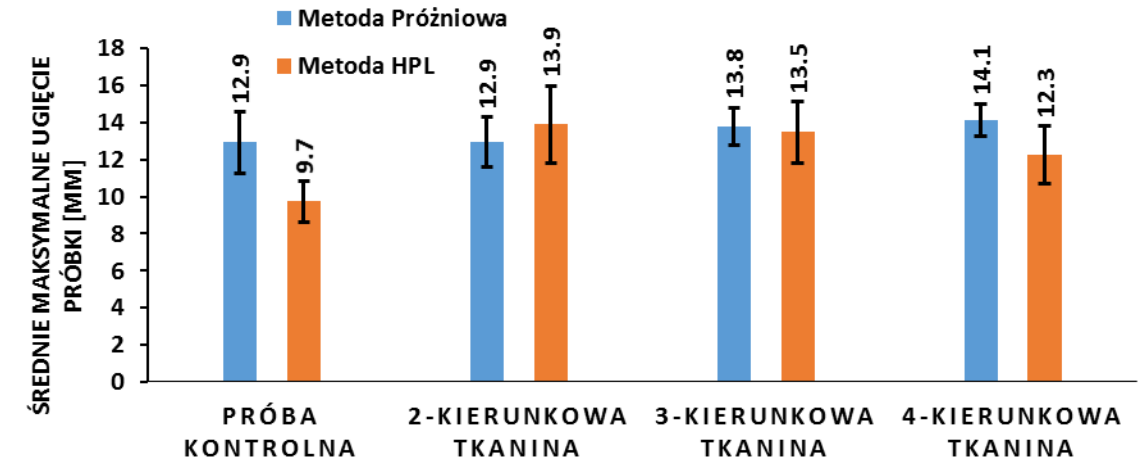

Rys. 6. Średnie maksymalne ugięcie próbki

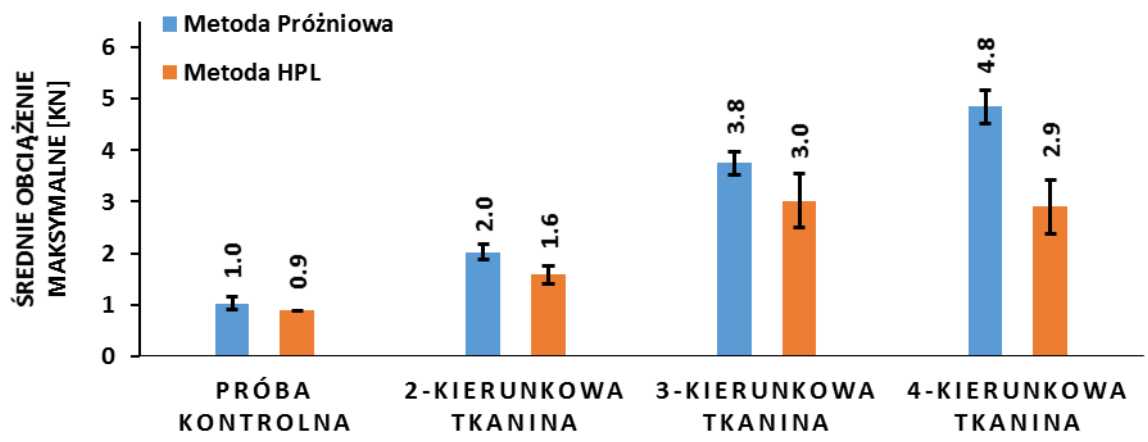

Rys. 7. Średnie obciążenie maksymalne próbki 
Reinforcing wooden composite with glass fiber fabric - manufacturing technology.. Zbrojenie kompozytu drewnianego włóknem szklanym - wpływ technologii...

Przebieg siły w funkcji przemieszczenia podczas zginania próbek, był zbliżony do liniowego.

W związku z tym przeprowadzono aproksymację liniową każdego testu i wyznaczono średnie sztywności próbek. Wyniki badań pokazują, że zbrojone próbki wykonane metodą próżniową są sztywniejsze o ok. $20-45 \%$, niż próbki wykonane metodą HPL (rysunek 8.), co w przypadku deskorolek, jest cechą niepożądaną.

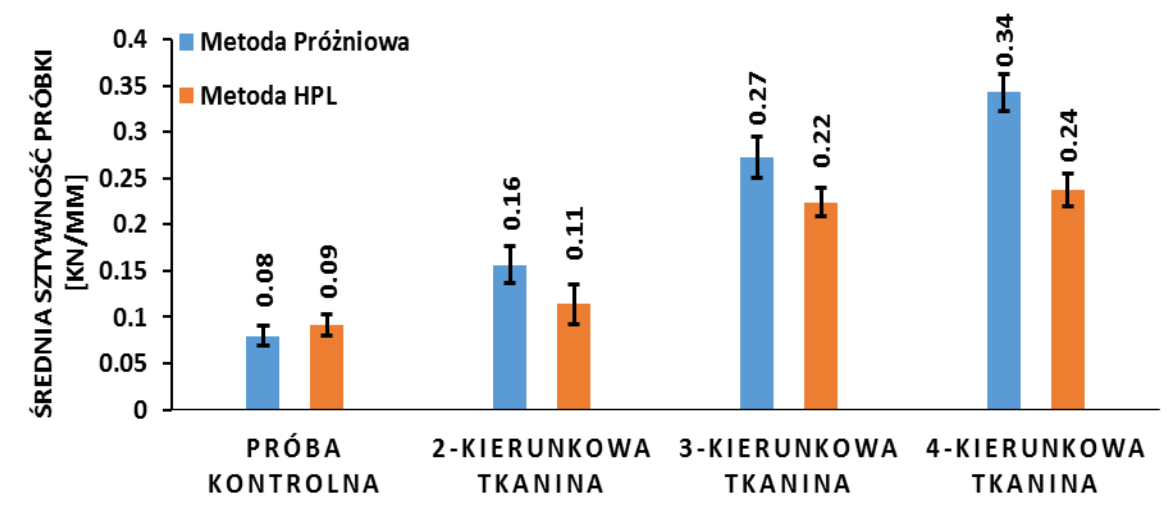

Rys. 8. Średnia sztywność próbek

$\mathrm{Na}$ koniec przeanalizowano jak wygląda stosunek maksymalnej siły do masy próbki (rysunek 9.), wyznaczając wskaźnik przenoszonego obciążenia na jednostkę masy gotowego kompozytu. W tym przypadku dla próbek wykonanych metodą próżniową, stosunek ten wypada lepiej o około $10-30 \%$. Może to świadczyć o zbyt małym udziale żywicy w próbkach wykonanych metodą HPL.

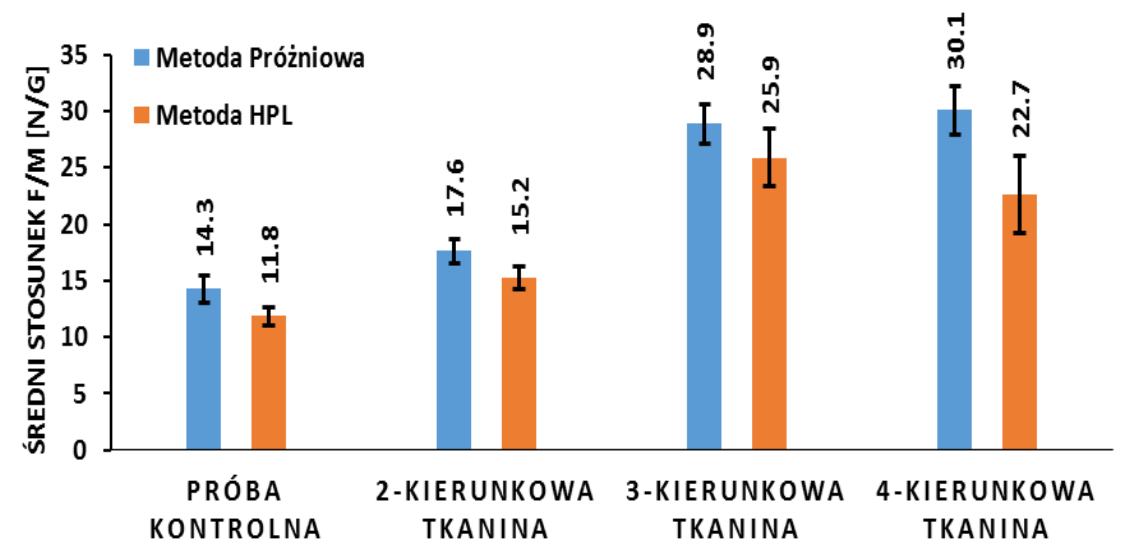

Rys. 9. Średni stosunek maksymalnego obciążenia próbki do jej masy Szczegółowe średnie wartości wyników badań eksperymentalnych przedstawiono w tabeli 3 . 
Tabela 3. Szczegółowe wyniki uzyskane z eksperymentów

\begin{tabular}{|c|c|c|c|c|c|c|}
\hline \multicolumn{7}{|c|}{ Próbki wytworzone metodą próżniową } \\
\hline & $\begin{array}{c}\text { Średnia } \\
\text { masa } \\
{[\mathrm{g}]}\end{array}$ & $\begin{array}{c}\text { Sredni } \\
\text { stosunek } \\
\text { masy } \\
\text { żywicy do } \\
\text { masy } \\
\text { tkaniny [-] }\end{array}$ & $\begin{array}{c}\text { Średnie } \\
\text { maksym. } \\
\text { ugięcie } \\
{[\mathrm{mm}]}\end{array}$ & $\begin{array}{c}\text { Średnie } \\
\text { obciąż. } \\
\text { maksym. } \\
{[\mathrm{N}]}\end{array}$ & $\begin{array}{c}\text { Średnia } \\
\text { sztywność } \\
{[\mathrm{kN} / \mathrm{mm}]}\end{array}$ & $\begin{array}{c}\text { Średni stos. } \\
\text { siły max. } \\
\text { do masy } \\
{[\mathrm{N} / \mathrm{g}]}\end{array}$ \\
\hline 1. & 71,78 & - & 12,9 & 1024,90 & 0,079 & 14,25 \\
\hline 2. & 113,67 & 0,61 & 12,9 & 2023,15 & 0,156 & 17,63 \\
\hline 3. & 129,86 & 0,62 & 13,8 & 3750,31 & 0,273 & 28,88 \\
\hline 4. & 161,80 & 0,64 & 14,1 & 4846,24 & 0,345 & 30,10 \\
\hline
\end{tabular}

\begin{tabular}{|l|c|c|c|c|c|c|}
\hline \multicolumn{7}{|c|}{ Próbki wytworzone metodą HPL } \\
\hline & $\begin{array}{c}\text { Średnia } \\
\text { masa } \\
{[\mathrm{g}]}\end{array}$ & $\begin{array}{c}\text { Sredni } \\
\text { stosunek } \\
\text { masy } \\
\text { żywicy do } \\
\text { masy } \\
\text { tkaniny }[-]\end{array}$ & $\begin{array}{c}\text { Średnie } \\
\text { maksym. } \\
\text { ugięcie } \\
{[\mathrm{mm}]}\end{array}$ & $\begin{array}{c}\text { Średnie } \\
\text { obciąż. } \\
\text { maksym. } \\
{[\mathrm{N}]}\end{array}$ & $\begin{array}{c}\text { Średnia } \\
\text { sztywnośćc } \\
{[\mathrm{kN} / \mathrm{mm}]}\end{array}$ & $\begin{array}{c}\text { Sredni stos. } \\
\text { siły max. } \\
\text { do masy } \\
{[\mathrm{N} / \mathrm{g}]}\end{array}$ \\
\hline 5. & 75,29 & - & 9,7 & 890,96 & 0,092 & 11,84 \\
\hline 6. & 104,40 & 0,50 & 13,9 & 1584,77 & 0,114 & 15,22 \\
\hline 7. & 116,07 & 0,54 & 13,5 & 3023,28 & 0,224 & 25,89 \\
\hline 8. & 127,73 & 0,38 & 12,3 & 2901,46 & 0,237 & 22,67 \\
\hline
\end{tabular}

\section{Dyskusja}

$\mathrm{Na}$ wstępie trzeba zaznaczyć, że prowadzone badania mają charakter analizy porównawczej, prowadzonej do celów produkcyjnych i nie odnoszą się w żaden sposób do innych kompozytów oferowanych na rynku. Badania przy użyciu tej samej metody i próbek o tym samym rozmiarze są nadal prowadzone przez grupę badawczą, celem dopracowania parametrów materiału oraz parametrów procesu technologicznego ich wytwarzania. Obecnie badania są już na zaawansowanym poziomie, a przedstawiona $\mathrm{w}$ tym artykule analiza miała charakter wstępny.

Rezultaty zestawienia wyników próbek wykonanych metodą HPL i próżniową mogą początkowo wydawać się zaskakujące. Metoda HPL, która jest bardziej zaawansowaną technologią okazała się generować, w niemal wszystkich analizowanych aspektach gorszy produkt. Okazało się, że próbki wykonane metodą próżniową, pomimo większej masy, mają wyższą wytrzymałość bezwzględną, lepszy stosunek maksymalnej siły do masy oraz wytrzymują większe ugięcie. Jedynie sztywność próbek wypadła na korzyść metody HPL, gdyż w deskorolkach preferowana jest nieznacznie mniejsza sztywność, celem poprawy właściwości jezdnych. 
Reinforcing wooden composite with glass fiber fabric - manufacturing technology.. Zbrojenie kompozytu drewnianego włóknem szklanym - wpływ technologii...

Przyczyn tej sytuacji może być kilka i najprawdopodobniej są to błędy w procesie technologicznym i zły dobór żywicy do technologii HPL. Przypuszcza się że, parametry procesu - temperatura i ciśnienie mogły być źle dobrane, przez co próbki owszem wychodziły lżejsze (ze względu na niższą zawartość żywicy), ale jednocześnie były przez to osłabione.

Zgodnie z oczekiwaniami, zwiększanie ilości warstw i kierunków zbrojenia laminatu włóknem szklanym w laminacie szklanym podnosi wytrzymałość kompozytu, co odzwierciedlają dane z Tabeli 3. Wyjątek stanowi dodanie czwartej warstwy, włókien poprzecznych, które z kolei daje różne rezultaty w zależności od metody wykonania próbki. Jednak nieznaczne polepszenie wytrzymałości próbek (metoda próżniowa) lub wręcz osłabienie kompozytu (metoda HPL), po dodaniu czwartej warstwy sugeruje, iż tkanina ta nie jest najlepszym wyborem na zbrojenie do produkcji deskorolek. Ciężko wskazać które zbrojenie będzie najlepsze. $\mathrm{Z}$ jednej strony tkanina 2- kierunkowa ma niższą sztywność sprawiając, że próbka jest bardziej elastyczna, jednocześnie uginając się do zbliżonej wartości co próbki zbrojone tkaniną 3- kierunkową, $\mathrm{z}$ drugiej strony poddaje się przy znacznie mniejszym obciążeniu. Dla ostatecznego wyboru lepszej konfiguracji wskazane będą dalsze badania, zarówno laboratoryjne, jak i badania „terenowe” gotowego produktu.

Jeżeli chodzi o metody wykonania kompozytu, to pomimo gorszych niż spodziewane rezultatów, nadal preferowaną metodą jest HPL. Jest kilka argumentów popierających ten wybór. Po pierwsze w metodzie HPL mamy większy zakres regulacji parametrów procesu produkcji, co daje większą swobodę doboru materiałów. Po drugie metoda próżniowa jest niewystarczająca do profilowania kształtów deskorolek. Konieczne byłoby zastosowanie autoklawy. Kolejny powód to szybkość procesu, który w przypadku metody HPL jest kilkukrotnie krótszy. Na koniec wypada wspomnieć, o aspekcie estetycznym. Korzystając $\mathrm{z}$ metody HPL łatwiej jest przygotować produkt o obydwu powierzchniach idealnie równych.

\section{Podsumowanie i wnioski}

Podsumowując przeprowadzone badania można wyciągnąc kilka istotnych dla produkcji wniosków. Przede wszystkim zaskakujące okazała się mniejsza skuteczność zastosowania metody HPL, w porównaniu do metody próżniowej. Prawdopodobnie wynika to ze złego doboru parametrów procesu prasowania. Zgodnie z oczekiwaniami, po zwiększeniu ilości warstw i kierunków zbrojenia włóknem szklanym otrzymaliśmy wzrost wytrzymałości kompozytu. Co więcej udało się wytypować preferowane systemy zbrojeń, dla później preferowanych właściwości mechanicznych - sztywności i wytrzymałości. Konieczne jest jednak 
przeprowadzenie dalszych badań i analiz, ukierunkowanych $\mathrm{w}$ stronę udoskonalenia parametrów procesu wytwarzania kompozytów preferowaną metodą HPL, jak i próba doboru innej żywicy. Badania nad tą tematyką sa nadal prowadzone.

\section{Literatura}

[1] Maciej Roszkowski, Mam jacht: Zakupy, Naprawy, Przebudowy, Alma-Press Sp. Z o.o., 2013.

[2] Strona internetowa: http://alternativelongboards.pl/

[3] Gibson Roland F., Principles of composite material mechanics, Third edition. CRC Press, 2012.

[4] Mallick P. K., Fiber-Reinforced Composites: Materials, Manufacturing, and Design, Third Edition. CRC Press, 2007.

[5] Polski Komitet Normalizacyjny: PN-EN ISO 178:2011/A1:2013-06 - wersja angielska.

[6] Polski Komitet Normalizacyjny: PN-EN 12135:2001 - wersja polska.

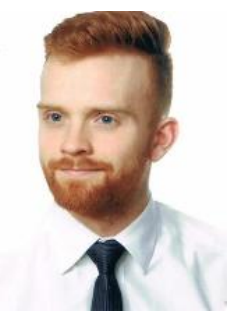

inż. Adam Deskiewicz w roku 2016 ukończyt studia I stopnia na Wydziale Mechanicznym Energetyki i Lotnictwa Politechniki Warszawskiej, na kierunku Aerospace Engineering. Obecnie jest studentem studiów II stopnia na tym samym wydziale. Zainteresowania naukowe to wytrzymatość struktur lotniczych, a także projektowanie załogowych oraz bezzałogowych statków powietrznych. (Udzial 40\%).

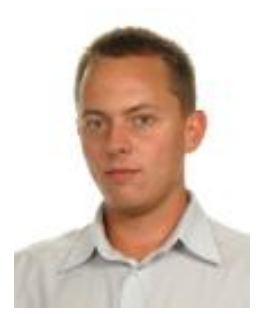

mgr inz. Michat Kowalik w roku 2009 ukończyt studia na Wydziale Mechanicznym Energetyki i Lotnictwa Politechniki Warszawskiej. Obecnie pracuje na stanowisku asystenta $w$ Instytucie Techniki Lotniczej $i$ Mechaniki Stosowanej Politechniki Warszawskiej. Zainteresowania naukowe to biomechanika, metody eksperymentalne mechaniki, naturalne i syntetyczne materiaty kompozytowe. (Udziat 15\%).

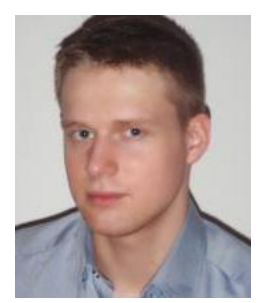

Michat Milewicz wspólzałożyciel oraz właściciel firmy Alternative Longboards. Od 2010 roku zajmuje się technologiami produkcji sprzętu do sportów deskowych. Entuzjasta projektów open source. Obecnie skupiony na rozwoju firmy oraz wprowadzaniu szeregu innowacji w procesie produkcyjnym desek longboardowych. Zainteresowania naukowe $i$ zawodowe to techniki wytwarzania, materiały do produkcji kompozytów na bazie żywic epoksydowych, mechanika i budowa maszyn, automatyka, elektronika, open source community. (Udziat 15\%). 
Reinforcing wooden composite with glass fiber fabric - manufacturing technology.. Zbrojenie kompozytu drewnianego włóknem szklanym - wpływ technologii...

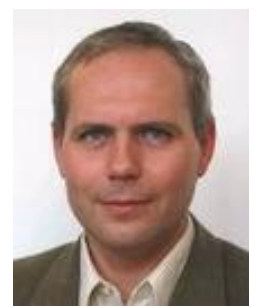

prof. nzw. dr hab. inż. Marek Matyjewski w roku 1988 ukończyt studia na Wydziale Mechanicznym Energetyki $i$ Lotnictwa Politechniki Warszawskiej. Stopień doktora nauk technicznych otrzymat w 1996 r., a stopień doktora habilitowanego w 2010 r. W roku 2015 mianowany na stanowisko profesora Politechniki Warszawskiej. Obecnie pracuje w Instytucie Techniki Lotniczej $i$ Mechaniki Stosowanej Politechniki Warszawskiej. Jest kierownikiem Zakładu Podstaw Konstrukcji. Zainteresowania naukowe to biomechanika, bezpieczeństwo bierne samochodów i niezawodność człowieka. (Udziat 10\%).

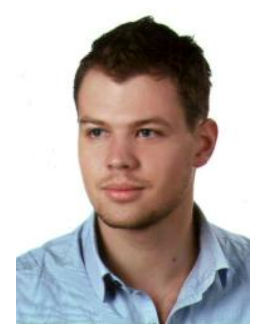

mgr inz. Rafal Andrzej Perz w roku 2010 ukończyt studia na Wydziale Mechanicznym Energetyki i Lotnictwa Politechniki Warszawskiej. Obecnie pracuje na stanowisku asystenta $w$ Instytucie Techniki Lotniczej $i$ Mechaniki Stosowanej Politechniki Warszawskiej. Zainteresowania naukowe to biomechanika obrażeń, bezpieczeństwo bierne pojazdów, badanie wypadków, niezawodność oraz materialy kompozytowe. (Udziat 20\%). 